\title{
Impact of Mining Activities on Estuarine Hydrological Regime and Benthic Life in Goa, India
}

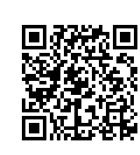

\author{
Parvez Al-Usmani SM* \\ DM's College and Research Centre, India
}

Submission: January 02, 2018; Published: September 04, 2018

Corresponding author: Parvez Al-Usmani SM, DM’s College and Research Centre, Assagao, Goa, India, Email: parvez_goa@yahoo.com

\begin{abstract}
The open caste mining in Goa for ferromanganese ore has generated a high amount of waste material rich in metal concentration. The discharge of such a great volume of waste is a potential eco-toxicological risk to the water quality and benthic life in several ways. The main objective of this study was to assess and evaluate the impact caused by large scale dumping of mining rejects on the hydrological condition and benthic community matrics. River Mandovi was considered for this study because of the major mining activities and dumping of waste is found in its upper reaches. For comparison, reference stations in Chapora River were selected, where such mining activities are not noticed. Data for macrobenthos and hydrological parameters were collected seasonally during 2010-2011 from three sites along the salinity gradient of both the estuaries. The hydrological parameters of the two estuaries were similar in range and mean but differed in suspended matter and metal (iron and manganese) concentration. The community parameters of the two estuaries showed clear difference. Total number of species recorded was 48 and 61 in Mandovi and Chapora, respectively. Average faunal density was $542 \pm 138$ and $733 \pm$ and diversity ( $\left.\mathrm{H}^{\prime}\right) 2.81 \pm 0.87$ and $3.55 \pm 1.04$ in Mandovi and Chapora, respectively. Polychaetes were by far the most dominant group ( $>50 \%)$ in both areas but differ in feeding type. The dominance of scavengers and absence of filter feeding forms in Mandovi was noticeable. Sediment mean size, salinity and metals appeared to have direct influence on the fauna distribution. Effects, attributable to mining apart from seasonal variation, included changes in species composition, reduction in total density, species diversity and other community attributes. The effect was conspicuously noticed in Mandovi as compared to Chapora.
\end{abstract}

Keywords: Open caste mining; Mine waste; Metal concentration; Hydrological condition, Benthic community matrics

\section{Introduction}

Environmental protection is a pre-requisite to a healthy economy and also to a society development. Mining in Goa for iron ore has been the most important economic activity contributing significantly to the state revenue over the years. The open cast mining of iron ore in Goa is an old industry. It has resulted in adverse effect on environment and water quality [1,2]. According to a report, for everyone tone of quality ore about three tones of waste is generated in an open cast mining (Anonymous, 1981). The discharge of mine waste and wash off of mining activities on passing through drainages reach downstream rivers and other water bodies and thus pollutes them because of a high concentration of iron in them [3]. Thereby, such water bodies often assume red colour, especially during the monsoon season. The heavy particles in marine suspended matter with high metal load gets settled in the estuarine system. The silt deposition blankets the bottom along the course of the water bodies, thus causes severe damage to benthic life and hydrological regime. The influence of heavy mining discharge and its potential damage to benthic life of the estuarine system of Goa is sparsely addressed.

The mining discharges increase the concentration of total suspended matter (TSM) in the tributaries and rivulets. According to a report about 3400 tonnes of TSM in Mandovi was recorded during monsoon period [4]. This has resulted in significant increase in the clay minerals and suspended solids in the entire course of the Mandovi estuary [5]. The increased turbidity has multiple disadvantages for the biological productivity in the aquatic environment [6]. The most important ecological concern associated with discharge of mine rejects is the leaching of metal into sediment and water, resulting in metal bioaccumulation in the marine food chain [7]. Thus, investigations on the ecological damages of such anthropogenic activity on environment and benthic assemblage assume great significance in understanding the implications on coastal biodiversity. The present study was undertaken in order to evaluate the extent and magnitude of the impact of the mine discharges on soft bottom macrobenthic community and the hydrological regime in estuarine system of Goa.

\section{Materials and Methods}

\section{Study area}

Majority of old mines were located along the banks of river Mandovi and hence this river was selected for the present 
investigation. Mandovi is connected with Zuari through a canal called Cumbarjua canal. Ore loading platforms are constructed along the bank of the river from where it is loaded on the barges and transported to harbour. Thus, the estuarine bed and associated mangroves located along the Mandovi are exposed to high influx of metal affluent from ferromanganese mining [7]. There is a report of high concentration of suspended solid from the mine tailing going on for several decades in the Mandovi estuary [2]. This discharge of clay and finely divided iron ore subjected the water column to continuous turbidity and the subtidal environment to continuous sedimentation by allochthonous particulate material [8]. River Chapora on the other hand does not have any mining activity along its traverse and was selected as a reference area for comparison and also to draw inferences [9].

\section{Field collection}

Sampling for benthos and environmental parameters was carried out in three seasons, post-monsoon (Oct-Nov 2010), pre-monsoon (Mar-Apr 2011) and monsoon (Aug-Sep 2011). On each sampling date, water, sediment and benthic fauna were collected from three locations spread about $5 \mathrm{~km}$ apart on a salinity gradient, in Mandovi and Chapora river estuary (Figure 1). Replicate samples were collected from each station on each sampling date. Water samples were taken with the help of a Niskin water sampler and sediment was collected with the help of a van Veen grab of $0.04 \mathrm{~m} 2$ area. Macrofauna samples were sieved through a $0.5 \mathrm{~mm}$ mesh sieve and preserved in formalin Rose Bengal solution. The $\mathrm{pH}$, water temperature and dissolved oxygen were measured in the field using a multi-parameter portable meter (EUTECH PCD 650, Japan). Water sample was also collected from each station for suspended solid (SS) and metal concentration. The water was filtered through a pre weighed $0.4 \mu \mathrm{m}$ Millipore filter paper. The SS retained on the filter paper was dried and weighted again.

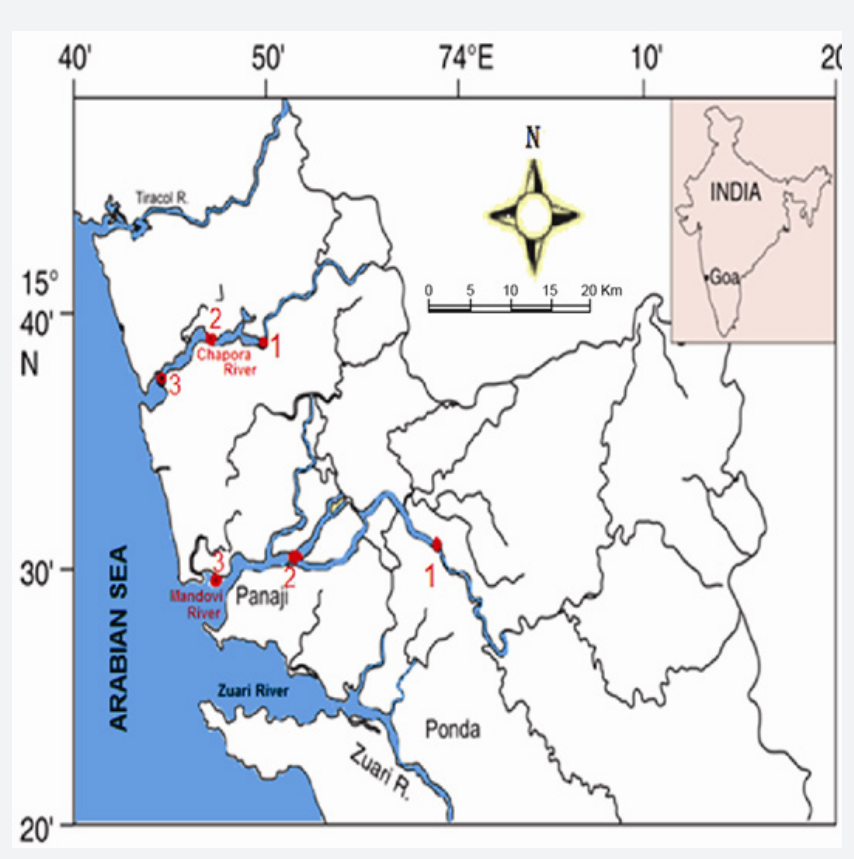

Figure 1: Sampling stations ( ) in Chapora and Mandovi estuaries.

\section{Laboratory analysis}

Water and sediment and tissue samples were analyzed for physico-chemical parameters by following the methodology given in APHA [10]. The sediment was analyzed for different fractions (sand, silt, clay) by the method of Buchanan [11]. Macrobenthic animals were sorted, identified to the lowest taxonomic level using literature, counted and weighed. The iron and manganese in water and sediment was analyzed by following the method given in Mesquita and Kaisary. The amount of Mn and Fe was detected using a flame Atomic Absoption Spectrometer (AAS, Perkin-Elmer Model 5000). Sediment organic carbon was estimated using titrimetric wet oxidation method as described by Allen et al. [12].

\section{Data analysis}

The numerical density and species richness of each site were analyzed by ANOVA after transformation of data to $\log 10$ when necessary. Possibilities $(\mathrm{p}<0.01)$ were considered statistically significant. Changes in community attributes such as abundance, species richness, diversity/dominance and structure of the benthic invertebrates assemblage under stress were studied by subjecting the data to univariate analysis for reference and effected sites. Various diversity indices are widely for comparison of community on spatial and temporal scale as well as for the assessment of environmental quality. This included Species richness, Shanon-Wiener diversity and species evenness. The degree of variability present in the macrofaunal 
assemblages in the impacted area were compared with that in the reference area following statistical software, PRIMER 6 (Plymouth Routine in Multivariate Ecological Research) [13].

\section{Result}

\section{Environmental characteristics of study area}

Mandovi and Chapora are monsoonal estuary and their flow of water is regulated by semi-diurnal tide. The hydrographical conditions are significantly influenced by the south-west

\section{Water quality characteristics of Mandovi}

Table 1: Average value of hydrographical parameters in the study area.

\begin{tabular}{|c|c|c|c|}
\hline \multicolumn{4}{|c|}{ Mandovi } \\
\hline Parameters & Post-monsoon & Pre-monsoon & Monsoon \\
\hline Temperature $\left({ }^{\circ} \mathrm{C}\right)$ & 27.8 & 29.4 & 24.2 \\
\hline Salinity (psu) & 14.8 & 24.6 & 5.8 \\
\hline Dissolved oxygen (mg/l) & 3.92 & 4.45 & 5.28 \\
\hline $\mathrm{pH}$ & 7.5 & 7.4 & 7.9 \\
\hline Suspended solid (mg/l) & 18.9 & 28.7 & 92.2 \\
\hline Fe (ppm) & 65.2 & 20.7 & 118.9 \\
\hline Mn (ppm) & 1.8 & 1.7 & 2.2 \\
\hline \multicolumn{4}{|c|}{ Chapora } \\
\hline Temperature $\left(\mathrm{C}^{\circ}\right)$ & 29.2 & 30.2 & 24.7 \\
\hline Salinity (psu) & 24.8 & 28.6 & 4.5 \\
\hline Dissolved oxygen (mg/l) & 3.76 & 3.68 & 6.82 \\
\hline $\mathrm{pH}$ & 7.9 & 7.5 & 7.4 \\
\hline Suspended solid (mg/l) & 0.52 & 0.45 & 1.64 \\
\hline Fe (ppm) & 0.15 & 0.12 & 0.18 \\
\hline Mn (ppm) & 0.01 & 0.06 & 0.08 \\
\hline
\end{tabular}

The hydrographical feature of the study area of Mandovi estuary which is influenced by the mining activities is presented in Table 1 . The surface water temperature of the study stations ranged between $28.2-30.9{ }^{\circ} \mathrm{C}$ in pre-monsoon, $23.8-25.6{ }^{\circ} \mathrm{C}$ in monsoon and $27.5-28.0{ }^{\circ} \mathrm{C}$ in the post monsoon season, respectively. The lowest temperature recorded in monsoon was as expected due to cloudiness and increased intensity of monsoon precipitation normally observed during this part of the season. The warming up of surface water takes place in October when the sky is clear and the annual average temperature along the transect, during post-monsoon varied between 26 and $28{ }^{\circ} \mathrm{C}$. The salinity in the Mandovi estuary varied widely, both seasonally and spatially due to tidal excursion. The observed values were in the range of $20.2-30.9$ psu in pre-monsoon, 1.08-9.25psu in monsoon and 8.9-20.5psu in post-monsoon, respectively. Lowest salinity was recorded in monsoon. During dry season the salinity keeps increasing, indicating intrusion of salt. The variation in salinity depends on intrusion during dry season and flushing during wet season. According to Shetye \& Murty [14], the estuary is flushed of salt during the wet season by freshwater entering the estuary at the upstream end. The monsoon (June-September). The freshwater discharge is highly The runoff in Mandovi increases two fold at lower down near Panaji due to many tributaries joining the main river unlike in Chapora. The runoff which is responsible for the washing of the mining rejects varies considerably. During the peak season it may be as high as $3400 \mathrm{McuM}$ and is negligible after cessation of monsoon. Due to the small catchment area, the hydrographical characteristics of Chapora river differs from that of river Mandovi. seasonal in these estuaries, markedly from wet to dry season.

dissolved oxygen (DO) content of the surface water at the study stations ranged from $4.2-4.7 \mathrm{mg} / \mathrm{l}$ in pre-monsoon, $4.6-6.5 \mathrm{mg} / \mathrm{l}$ in monsoon and 3.92 to $4.12 \mathrm{mg} / \mathrm{l}$ in post-monsoon, respectively. The values suggest that the surface water in the study area is well oxygenated. The maximum values were attained in monsoon when the estuary is almost a freshwater dominated body. The annual average concentration of DO in the transect stations varied between $4.02-5.6 \mathrm{mg} / \mathrm{l}$. The DO showed inverse relation with salinity. The $\mathrm{pH}$ values varied with a narrow range in all seasons. The values were in the range of 7.2-7.6 in pre-monsoon, 7.7-8.2 in monsoon and 7.2-7.6 in post-monsoon, respectively. The suspended solid (SS) was in the range of $26.5-32.2 \mathrm{mg} / \mathrm{l}$ in pre-monsoon, $83.4-110.6 \mathrm{mg} / \mathrm{l}$ in monsoon and $18.2-20.8 \mathrm{mg} / \mathrm{l}$ in post-monsoon. Variation in SS in the study transect is an indication of land drainage including discharges from mine tailings. Its magnitude is highest during the monsoon months and the variation in other months is regulated by the addition from land. The suspended solid coming from the mining areas situated along the river bank in the upper reaches is regularly flushed out by strong currents. 


\section{Water quality characteristics of chapora}

Table 2: Average values of sediment properties in the study area.

\begin{tabular}{|c|c|c|c|}
\hline \multicolumn{4}{|c|}{ Mandovi } \\
\hline Parameters & Post-monsoon & Pre-monsoon & Monsoon \\
\hline Sand (\%) & 44.6 & 51.3 & 44 \\
\hline Silt (\%) & 25.6 & 21.3 & 32.4 \\
\hline Clay (\%) & 29.8 & 21.4 & 23.5 \\
\hline TOC (\%) & 1.67 & 1.5 & 2.1 \\
\hline $\mathrm{Fe}(\mathrm{ppm})$ & 76.3 & 109.2 & 108.5 \\
\hline Mn (ppm) & 1.4 & 1.7 & 0.8 \\
\hline \multicolumn{4}{|c|}{ Chapora } \\
\hline Sand (\%) & 71.6 & 51.3 & 44 \\
\hline Silt (\%) & 20.5 & 21.3 & 32.4 \\
\hline Clay (\%) & 7.9 & 21.4 & 23.5 \\
\hline TOC (\%) & 1.12 & 1.09 & 0.78 \\
\hline $\mathrm{Fe}(\mathrm{ppm})$ & 15.7 & 14.2 & 17.4 \\
\hline Mn (ppm) & 0.14 & 0.19 & 0.35 \\
\hline
\end{tabular}

The results of the hydrographical parameters of the Chapora river estuary (reference area) are given in Table 2. The water quality appears to follow a definite seasonal pattern. The water temperature during post-monsoon was in the range of 28.5$29.6{ }^{\circ} \mathrm{C}$, in pre-monsoon $29.6-31.8{ }^{\circ} \mathrm{C}$ and in monsoon 24.7 25.9 oC. The salinity was high in post- and pre-monsoon and the values ranged from $21.4 \mathrm{psu}$ in post-monsoon to $30.2 \mathrm{psu}$ in pre monsoon. The monsoon recorded the lowest values of 1.88-8.16psu. The dissolved oxygen (DO) recorded moderate to high values with a range of $3.52-3.98 \mathrm{mg} / \mathrm{l}$ in post-monsoon and 3.43-4.22mg.l in pre-monsoon. High values (5.25-6.47mg/l) were however, recorded in the monsoon season. The $\mathrm{pH}$ was always above 7. The suspended solid remained significantly low even during the monsoon season. The minimum value of SS was $0.22 \mathrm{mg} / \mathrm{l}$ recorded in pre-monsoon while the maximum of $1.85 \mathrm{mg} / \mathrm{l}$ was recorded in monsoon season.

\section{Sediment}

Table 3: Macrofaunal abundance in the study area- values are range and means (in parenthesis).

\begin{tabular}{|c|c|c|c|}
\hline \multicolumn{5}{|c|}{ Mandovi } \\
\hline Station & $\mathbf{1}$ & $\mathbf{2}$ & $\mathbf{3}$ \\
\hline Density $\left(\mathrm{No} . / \mathrm{m}^{2}\right)$ & $128-236(204)$ & $258-1027(516)$ & $352-1377(876)$ \\
\hline Biomass $\left(\mathrm{g} / \mathrm{m}^{2}\right)$ & $3.74-6.02(4.16)$ & $8.63-12.29(9.76)$ & $14.45-29.36(18.55)$ \\
\hline \multicolumn{7}{|c|}{ Chapora } \\
\hline Density $\left(\mathrm{No} / \mathrm{m}^{2}\right)$ & $136-382(278)$ & $388-1522(828)$ & $476-1618(928)$ \\
\hline Biomass $\left(\mathrm{g} / \mathrm{m}^{2}\right)$ & $4.28-7.923(5.38)$ & $10.22-14.62(11.76)$ & $16.25-30.82(20.18)$ \\
\hline
\end{tabular}

Table 4: Average value of community parameters of benthos in the study area.

\begin{tabular}{|c|c|c|c|}
\hline Parameters & Post-monsoon & Pre-monsoon & Monsoon \\
\hline \multicolumn{4}{|c|}{ Mandovi } \\
\hline Number of species/m2 & 35 & 36 & 17 \\
\hline Species richness (D) & 4.28 & 5.02 & 3.59 \\
\hline Species diversity (H') & 3.14 & 3.42 & 1.97 \\
\hline
\end{tabular}


Oceanography \& Fisheries Open access Journal

\begin{tabular}{|c|c|c|c|}
\hline Evenness (j) & 0.98 & 0.95 & 1 \\
\hline \multicolumn{4}{|c|}{ Chapora } \\
\hline Number of species/m2 & 38 & 42 & 24 \\
\hline Species richness (D) & 5.64 & 5.98 & 3.67 \\
\hline Species diversity $\left(\mathrm{H}^{\prime}\right)$ & 3.86 & 3.92 & 2.04 \\
\hline Evenness (j) & 0.98 & 0.96 & 0.95 \\
\hline
\end{tabular}

The iron values in water were found to be in the range of 20.7 to $118.9 \mathrm{ppm}$ in Mandovi estuary and 0.12 to $0.18 \mathrm{ppm}$ in Chapora estuary (Table 5.1). Similarly, the manganese values were in the range of 1.7 to $2.2 \mathrm{ppm}$ in Mandovi and 0.01 to $0.05 \mathrm{ppm}$ in Chapora estuary. During the pre-monsoon, concentration of Fe in water from Mandovi estuary was found to be $20.7 \mathrm{ppm}$ while, water from Chapora had Fe content of $0.12 \mathrm{ppm}$. During the monsoon season, the iron content was 118.9ppm in Mandovi and $0.18 \mathrm{ppm}$ in Chapora whereas, during the post-monsoon season; the values recorded were $65.2 \mathrm{ppm}$ in Mandovi and $0.15 \mathrm{ppm}$ in
Chapora estuary. Thus, a difference of an order of significant magnitude of metal contents were observed, ranging from high to very high concentrations of Fe in water from Mandovi and low concentration of Fe in water from Chapora. Seasonal variation of Mn concentration in waters from Chapora river was from a minimum of $0.02 \mathrm{ppm}$ (monsoon season) to maximum of $0.06 \mathrm{ppm}$ (pre-monsoon season). Whereas, on the other hand, seasonal Mn values in waters from Mandovi estuary showed a variation from $1.7 \mathrm{ppm}$ (pre-monsoon season) to $2.2 \mathrm{ppm}$ (monsoon season).

\section{Macrobenthos abundance}

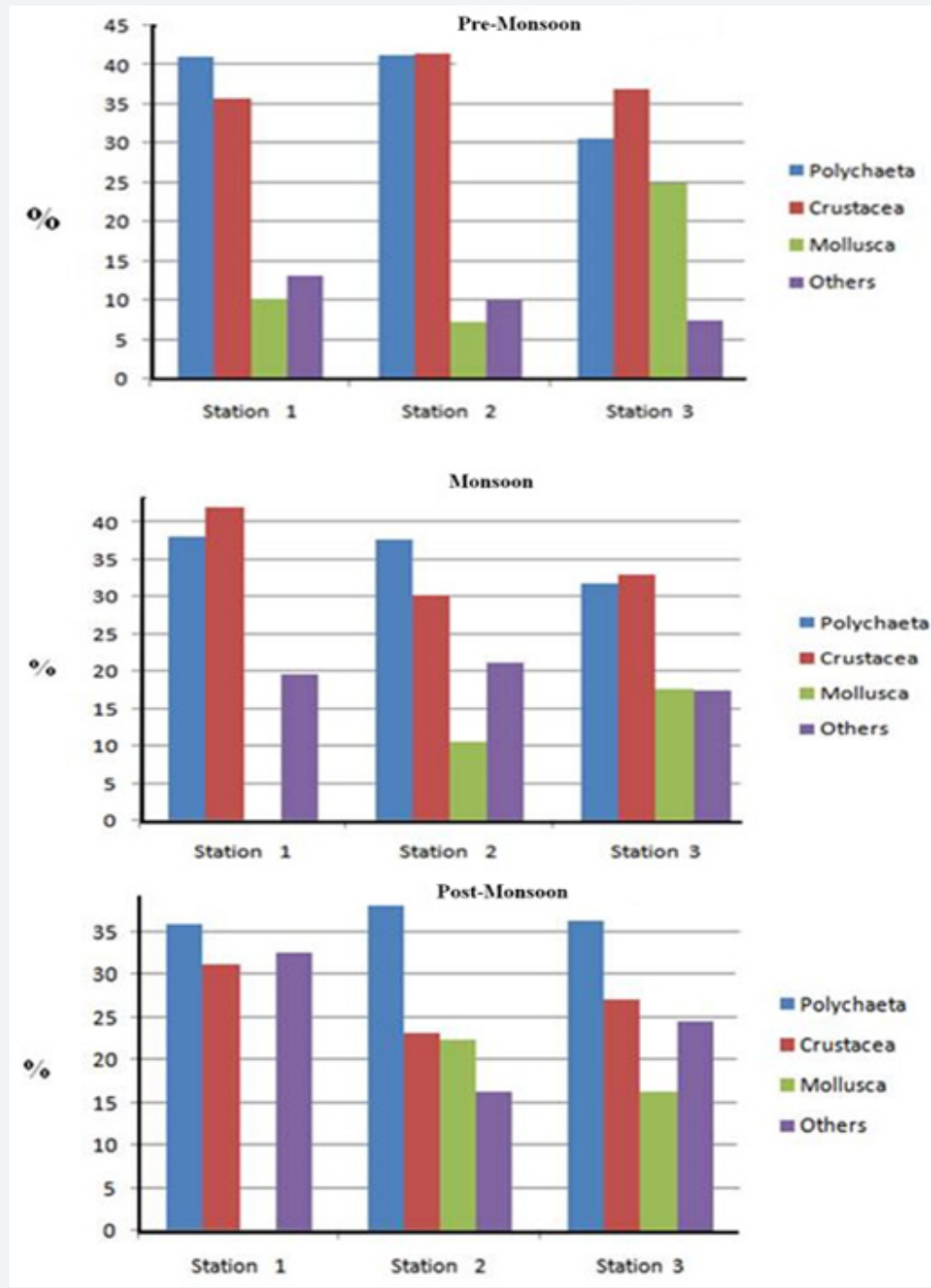

Figure 2: Percentage contribution of major benthic groups in each season in Mandovi. 
A total of 4882 animals were collected from three locations in the Mandovi estuary during the study period (Table 3). The lowest density $\left(\mathrm{no} / \mathrm{m}^{2}\right)$ was recorded in the upper mesohaline (5-18psu) area (station \#1) and high density in the euhaline (32psu and >) at station \#3. Intermediate abundances were also observed in the middle part of the estuary (St. \#2) which falls in a polyhaline area. Highest density in the euhaline zone located in the mouth region, several $\mathrm{km}$ down from the intense mining activity was recorded. The macrofaunal density ranged from 128 to $236 / \mathrm{m}^{2}$ at St. \#1, 254 to $1027 / \mathrm{m}^{2}$ at St. \#2 and 352 to $1377 /$ $\mathrm{m} 2$ at St. \#3 (Table 3). Similarly the biomass ranged between 3.74 to $6.02 \mathrm{~g} / \mathrm{m}^{2}$ at St.\#1, 8.63 to $12.29 \mathrm{~g} / \mathrm{m}^{2}$ at St. \#2 and 14.45 to $29.36 \mathrm{~g} / \mathrm{m}^{2}$ at St. \#3. The average density was lowest at St. \#1 and highest at St. \#3. The inter-sample differences were also recorded at three sites. The fauna comprised of three main groups, the polychaeta, crustacean and mollusca. Minor phyla comprised the other groups (Figure 2).

Polychaeta was the dominant group at all three stations and its percentage contribution was in the range of 36.0-41 at St. \#1, 37.2-41.2 at St. \#2 and 31.8-36.3 at St. \#3. The crustaceans were second in the order of abundance and contributed 31.3-42.1\% at St. \#1, 23.1 -41.5 at St. \#2, 27.1-37.0 at St \#3. In some cases the abundance of crustacean was more than that of polychaeta. Similarly, the mollusca contribution was in the range of $0-10.2 \%$ at St. \#1, 7.3-22.4 at St. \#2 and 12.1-24.9\% at St. \#3. The seasonal average contribution suggested that polychaeta and crustacean were significant in percentage contribution. The mollusca contribution was insignificant. The other group was formed by minor phyla contributed by sipunculida, Echiurida, nematode and nemertina. The contribution of this group together was higher than that of mollusca.

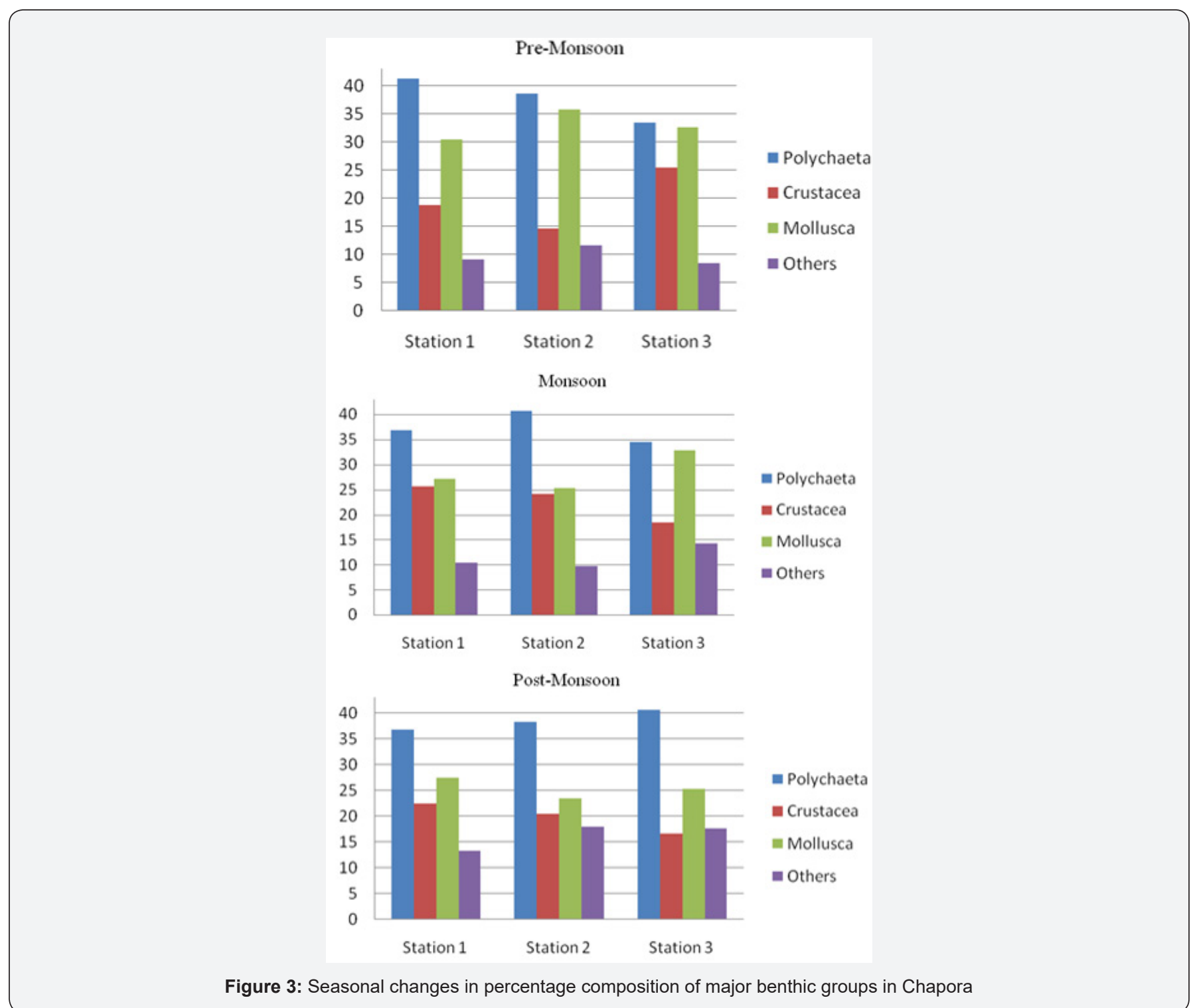

The benthic abundance in the reference area of Chapora recorded very high density and strong seasonality in the occurrence (Table 3). A total of 5705 individuals were collected from three sites. The average density was 278, 828 and 928 at St. \#1, St. \#2 and St. \#3, respectively. The lowest average density of $278 / \mathrm{m}^{2}$ was recorded in monsoon at St. \#1 and the 
highest average density of $928 / \mathrm{m}^{2}$ in pre-monsoon season at St. \#3. Thus, a variation in distribution was also noticed along the salinity gradient; the low number present at lower salinity while the higher number recorded in the high saline zone. The dominant taxa in the order of abundance were polychaeta (33.4$41.2 \%$ ), mollusca $30.4-35.8 \%$ ) followed by crustacean (16.6$22.6 \%$ ) (Figure 3). The other groups include a number of minor phyla such as anemonia, sipuncula, echiurida, anthopleura and nematoda. The polychaeta and mollusca were similar in distribution while crustacean were significantly lower in abundance as compared these species to found in Mandovi.

\section{Community parameters}

The values of community parameters are given in Table 4. The occurrence of species in Mandovi showed clear seasonal variation. During monsoon lowest values were recorded and in pre-monsoon season highest values were observed. The species richness (D) was in the range of 3.59 and 5.02 and species diversity $\left(H^{\prime}\right) 1.97$ and 3.42. The evenness was similar in all season. In the Chapora the number of species recorded ranged between 24-42, the species richness 3.67-5.98 and species diversity $\left(H^{\prime}\right)$ 2.04-3.92. The seasonal range of variation in the two areas was similar but the average values in Chapora were higher than in that of Mandovi.

\section{Major species contribution}

In the present study, 46 species of macrobenthos were identified in Mandovi. This included 21 species of polychaetes. The macrobenthos of Chapora was characterized by the presence of 56 species belonging to polychaeta, crustacean and mollusca in different seasons. The occurrence of dominant and abundant species in the two areas is given Table 5. There was seasonal variability in the occurrences. There was more dominance of polychaete worms in both estuary. The dominance of opportunistic group such as Prionospio pinnata, dendronereis aestuarina, Mediomastus sp. Nephtys polibranchiata and scavenging and seston feeding crustaceans, such as Ampelisca sp., Corophioum sp. Cyathura sp., Tanaidacea, and Ostracoda in the Mandovi was the result of condition developed due to mining discharges. This is supported, in parallel, by the absence of many filter feeding forms such as bivalves. On the other hand the Chapora showed normal distribution of macrofauna with more number of polychaeta species such as Nereis capensis, Lumbroconereis sp., Onuphis sp. Diopatra neapolitana and Polydora ciliate, Prionospio cirifera, and high density of suspension/and filter feeding forms such as Meretrix casta, Paphia textile, Tellina sp., and Cyclospis sp. The order of dominance of major group was polychaeta, crustacean and mollusca in Mandovi while polychaeta, bivalvia and crustacea in Chapora. The estuarine fauna of Mandovi and Chapora follows seasonality in the distribution, with low number in monsoon and high in pre-monsoon (Plate 1).

\section{Physico-chemical and biological parameters inter- relationship}

In order to study the inter-association of physico-chemical and biological parameters and their interdependence, the correlation coefficient were analysed for Mandovi and Chapora and the results are presented in Table a $\&$ b. The values were tested at $p<0.05, p<0.01$ and $p<0.001$ level of significance. In the first case of Mandovi salinity-temperature showed highly significant positive correlation $(r=0.94, p<0.001)$. The suspended solid was positively correlated with dissolved oxygen $(\mathrm{r}=088, \mathrm{p}<0.01)$. Among biotic parameters macrofaunal density showed significant positive correlation with dissolved oxygen $(\mathrm{r}=0.77, \mathrm{p}<0.05)$, ph $(\mathrm{r}=0.72, \mathrm{p}<0.05)$ and suspended solid $(\mathrm{r}=0.73, \mathrm{p}<0.05)$. The density and diversity were negatively correlated with sedimentary $\mathrm{Fe}(\mathrm{r}=-0.78, \mathrm{p}<0.05)$ and $\mathrm{Mn}$ $(\mathrm{r}=-0.84, \mathrm{p}<0.01)$. The diversity showed significant positive relationship with density $(\mathrm{r}=0.73, \mathrm{p}<0.01)$. The density showed significant positive correlation with DO ( $\mathrm{r}=0.77, \mathrm{p}<0.05)$, ph $(\mathrm{r}=0.72, \mathrm{p}<0.05)$ and suspended solid $(\mathrm{r}=0.73, \mathrm{p}<0.05)$. The high negative association between biotic parameters and metal suggest their negative effect on benthos.

Table 5: Dominant species in different season. Numbers in parenthesis indicate percentage composition in each season.

\begin{tabular}{|c|c|c|c|}
\hline Stations & Premonsoon & Monsoon & Postmonsoon \\
\hline Mandovi & $\begin{array}{c}\text { Dendronereis aestuarine, (20), Glycera alba, } \\
\text { (11), Prionespio pinneta, (22), Paraprionospio } \\
\text { patiens, (14), Meretrix casta, (6) Ostracoda (8), } \\
\text { Tanaidacea (10), Nephtys polibranchiata (6), } \\
\text { Cyclaspis sp. (12), }\end{array}$ & $\begin{array}{c}\text { Mysidacea, (12) Corophium sp., (16) } \\
\text { Prionospio pinnata (7) Cosura sp. (9) } \\
\text { Paphia malabarica (8) Ampelisca sp. (4) } \\
\text { Amphithoe sp (5) Photis sp. (7) }\end{array}$ & $\begin{array}{l}\text { Cossura sp., (14) Nephtys sp. (19) } \\
\text { Cirratulus sp. (5) Magelona cincta (7), } \\
\text { Lumbriconereis sp. (5) Glucera alba, (6) } \\
\text { Natomastus sp. (5) Ampelisca sp. (8) } \\
\text { Cyathura sp. (8) }\end{array}$ \\
\hline Chapora & $\begin{array}{c}\text { Nereis capensis, (12) Lumbrinereis sp. } \\
\text { (18), Onuphis sp. (9), Polidora ciliate (12), } \\
\text { Corophium sp (11). Marginella sp (8). Tellina } \\
\text { sp (7). Diopatra neapolitana (8). Paphia textile, } \\
\text { (7) Meretrix casta, (6) Modiolus metcalfi (6) }\end{array}$ & $\begin{array}{c}\text { Paphia textile, (9), Meretrix casta, (12), } \\
\text { Ampithoe sp. (6) Diopatra neapolitana } \\
\text { (16) Ampelisca sp. (8) Marginella sp. (8) } \\
\text { Cirithedia morus, (10), Eurydice sp (6). } \\
\text { Polydora ciliate (10) }\end{array}$ & $\begin{array}{c}\text { Prionospio cirifera, (12) Donax cuneatus, } \\
\text { (8), Corophium sp., (7), Cyathura sp. (6) } \\
\text { Diopatra neapolitana (10), Polidora } \\
\text { ciliata, (13), Tainadacea (8), Cyclaspis } \\
\text { sp. (11) }\end{array}$ \\
\hline
\end{tabular}

The correlation coefficient matrix for Chapora suggested highly significant relation between temperature and salinity $(\mathrm{r}=0.94, \mathrm{p}<0.001)$. DO showed significant negative relation with temperature $(r=-0.79, \mathrm{p}<0.05)$ and salinity $(r=-0.88$, $\mathrm{p}<0.01$ ). Suspended Solid demonstrated a significant negative relation $(\mathrm{p}<0.01)$ with temperature, salinity and DO. Among biotic parameters, diversity showed positive significant relation with temperature $(\mathrm{r}=0.84, \mathrm{p}<0.01)$, salinity $(\mathrm{r}=0.85, \mathrm{p}<0.01)$. Diversity was negatively related with suspended solid $(r=-0.77$, $\mathrm{p}<0.05)$ and $\mathrm{Fe}(\mathrm{r}=-0.80, \mathrm{p}<0.01)$. Interestingly, the density was poorly related to other parameters unlike noticed in Mandovi, thus suggesting no adverse effect on benthos. 


\section{Discussion}

The hydrographical feature of the Mandovi river- estuary has been studied fairly extensively and there is a great deal of information available on water temperature, salinity, DO, SS, chemical properties, water currents and water flow pattern [1517]. The most important feature emerging from these studies is that the hydrographical features are found to be fairly regular and follow the seasonal cycle. The intense precipitation and land runoff during the monsoon bring about large changes in water quality and sediment regime. During the dry season, the season (post-monsoon) the water in the estuarine region remains well mixed and marine condition develop in the premonsoon season [14]. The concentration of dissolved oxygen is influenced by biological and physico-chemical processes. The gross factors controlling its solubility are water temperature, salinity and humidity. High oxygen saturation during monsoon period has also been reported by many researchers. There were no significant differences in the hydrological parameters of the two estuaries.

The high value of $\mathrm{Fe}$ and $\mathrm{Mn}$ in water and sediment of Mandovi as compared to reference sites in Chapora is attributed to the transport of ferromanganese ore through Mandovi and high precipitation of mining waste discharges. In a recent study, Attri \& Kerkar [7] reported high to very high concentration of $\mathrm{Fe}$ and $\mathrm{Mn}$ in the mangrove sediment of Mandovi and low concentration in Chapora which was related to mining activity. The high concentration could be explained by the strong association of the geo-chemical matrix between the two elements of Fe and Mn. Information biological characteristics of Mandovi estuary particularly on chlorophyll, phytoplankton abundance, zooplankton production [18] and benthos is available [19]. In recent studies, significant changes in benthos feeding type associated with large changes in water quality and sediment granulometry due to anthropogenic activity including mining has been reported $[20,21]$.

The suspended solid (SS) recorded significantly high values in Mandovi as compared to Chapora. This is the result of large mining washing and its discharge in the Mandovi estuary and concentrated mining activity in the upper reaches of the Mandovi [17]. A low SS observed in chapora could be attributed to no mining activity along its bank. Kessarkar et al. [8] have reported high spatio-temporal variability in suspended solids in Mandovi river which is attributed to mining activities. The settlement of sediment in the river is largely affected by river discharge and settling velocities of sediment. Thus the heavier particles settle faster within the mining zone while the red clay particles, characteristics of mining dust move forward and settle [4].

The sediment in the Chapora estuary is predominantly sandy in all season with little percentage variation of silt and clay. Earlier studies in Chapora have also suggested strong seasonality in hydrological and sediment granulometry changes $[9,22]$. The benthic fauna also showed seasonal variation and the fauna was dominated by mollusca and polychaeta. The third group was represented by crustacea but in low percentage. In an ecological study of Chapora bay-estuarine system, Untawale \& Dhargalkar [23] have reported high benthic production, dominated by filter feeding bivalves such as Meretrix casta and Perna viridis According to them the benthic production of the bay was high due to high organic production and was dominated by filter feeding edible bivalves such as Meretrix cast, Perna viridis and gastropods. They have also found very low percentage of epibenthic crustaceans as observed in the present study.

The metal values recorded in the water and sediment was within the limit recorded by Attri \& Kerkar [7] for the same area. The results of the present study on correlation matrix agrees with Snelgrove \& Butman [24] who concluded that with the exception of extreme habitats benthic community in the coastal zone is not controlled by one or a simple combination of parameters. An ideal habitat for benthic animals like worms, bivalves is the soft sediment, a combination of sand silt and clay. Any change in bottom deposit such as red clay, cobbles and pebbles, as observed in Mandovi estuary, will deter the settlement and growth of suspension, deposit feeder and other infaunal benthic invertebrates [20]. The dominance of polychaete filter feeders and scavenging crustaceans is reported for a disturbed area in Zuari estuary of Goa [25]. This in conformity with the observations made in this study.

High degree of impoverishment in macrobenthic community with decrease in abundance and species richness due to shoreline discharge of iron ore mine tailing in Chile was reported by Lancellotti \& Stotz [26]. The impoverishment of fauna in particularly in Mandovi is related to anthropogenic disturbances. The benthic larvae settlement on altered deposit is affected due to increase in suspended solid. It will choke the filtration apparatus with possible mortality of the infaunal assemblage. Thus, the present study suggests towards decline and impoverishment in native benthic animals, in particular, reduction in filter feeding bivalves, deposit feeding polychaetes and increase in seston feeding forms and scavengers such as crustacea. In earlier studies, reduction in macro and meiobenthos of Goa estuaries due to mining activity have been reported $[20,2728]$. In another study, Pancham et al. [29] observed significant decline in the number and species of foraminiferans of Mandovi estuary which have related to mining pollution. The sand excavation and removal from the river bed has aggravated the situation. High density bed of estuarine clam, Meretrix casta $(>1000 / \mathrm{m} 2)$ once existed in the estuary, has reduced to few numbers in the present study. The abatement of the recurrence of such a phenomenon is the only solution which will help in resettlement of the high benthic diversity of the affected Mandovi river-estuary [30-33].

\section{Summary and Conclusion}

The anthropogenic interferences along with natural disturbances have yielded varied results globally in the past. Mining was the backbone of economy in Goa; however, illegal 
mining in the past decade has caused severe damage to the ecology, hydrology and agriculture. This study was aimed to provide information on effect of mining on hydrology and benthic community in Goa. The impoverished macrofaunal assemblage including filter feeders and dominance of scavengers in the affected Mandovi estuary as compared to high density, diversity, richness and dominance of filter feeding polychaetes and bivalves in reference area of Chapora was noticeable. This is the direct effect of turbidity of water column, sedimentation of the bottom due to discharge of mine tailing which were probably responsible for dissimilarity in faunistic composition in the two areas under consideration. Although the climate induced changes including the temporary ban on mining might have brought reduction in waste discharges, the negative effect on the macro-invertebrate community of Mandovi due to mining discharge is clearly evident in the present study. For a healthier estuarine condition more flushing is required bring the positive effect on estuarine benthic fauna.

\section{Acknowledgement}

The author is thankful to the Principal, Dr. Arolkar DB of DM's College and Research Centre, Assagao for his encouragement. I am also thankful to my research supervisor, Dr. Jagtap TG and Prof. D.N. Patil for their suggestions in improving the manuscript.

\section{References}

1. Ganihar SR (1990) Impact of mining on the faunal composition of Goa. Ph.D. thesis submitted to Goa University (unpublished). pp. 1-264.

2. Nayak GN (2002) Impact of mining on environment in Goa. India International Publisher, New Delhi, India, p. 112.

3. Kessarkar PM, Suja S, Sudheesh V, Srivastava S, Rao P (2015) Iron ore pollution in Mandovi and Zuari estuarine sediment and its fate after mining ban. Environmental monitoring and Assessment 187(9): 1-29.

4. Nayak GN (1993) Studies on sediment flux of rivers, estuaries and adjoining coastal waters of Goa, west coast of India. Technical report submitted to Department of Environment and Forest, pp. 1069.

5. Bukhari SS, Nayak GN (1996) Clay minerals as path finders of sediment source in Mandovi estuary of Goa, India. Indian Journal of Marine Sciences 25: 341-354.

6. Hiremath KG, Shetty SM (1987) Studies on the phytoplankton in some of the streams at the iron ore mining areas. In: Effect of mining on the ecosystems of Sanguem, Bicholim, Sattari, and Quepem talukas, Goa. Technical report, pp. 21-27.

7. Attri, Kuldeep, Kerkar S (2011) Seasonal assessment of heavy metal pollution in tropical mangrove sediment (Goa, India). Journal of Ecobiotechnology 3(8): 9-15.

8. Kessarkar PM, Rao VP, Shynu R (2010) Nature and distribution of particulate matter in the Mandovi estuary, central west coast of India. Estuaries and Coasts 33(1): 30-44.

9. Babu KD (2009) Water quality characteristics of Chapora river north Goa. M.Sc. Dissertation, Bharathidasan University, India.

10. APHA (1986) Standard method for examination of water wastewater specifications. American Public Health Association, NW, DC, 20036, (19 th $^{\text {th }}$ ) .

11. Buchanan JB (1984) Sediment analysis: In: Holme NA, McIntyre AD (Eds.), Methods for the study of marine benthos. Blackwell scientific publication, USA.
12. Allen SE, Grimshaw HM, Parkinson JA, Quarmby C, Roberts JD (1976) Chemical analysis in methods in plant ecology. Chapman, SB, editor, Oxford, Blackwell scientific publication, Chapter 13: 411-466.

13. Warwick RM, Clarke KR (1991) A comparison of some methods for analyzing changes in benthic community structure. Journal of Marine Biological Association, UK, 71(1): 225-244.

14. Shetye SR, Suresh I, Sundar D (2007) Tide and sea level variability. In: Shetye SR, Dileep Kumar M, Shankar D (Eds.), The Mandovi and zuari estruaries. National Institute of Oceanography pp. 29-38.

15. Qasim SZ, Sen Gupta R (1981) Environmental characteristics of the Mandovi-Zuari estuarine system in Goa. Estuarine, Coastal \& Shelf Science 13(5): 557-578.

16. Shetye SR, Gouveia AD, Singbal SYS, Naik CG, Sundar D, et al. (1995) Propagation of tides in the Mandovi-Zuari estuarine network. Proceedings of Indian Academy of Sciences (Earth and Planetary Sciences) 104: 667-682.

17. Bukhari SS, Nayak GN (2000) Seasonal variation of suspended matter and associated parameters in a tropical estuary, central west coast of India. Dharwad Special publication 2: 57-78.

18. Goswami SC (1979) Secondary production in the estuarine inshore and adjacent waters of Goa. Ph.D. Thesis Punjab University, Chandigarh, India, p. 207.

19. Parulekar AH, Dhargalkar VK, Singbal SYS (1980) Benthic studies in Goa estuaries. Part III. Annual cycle of macrofauna distribution, production and trophic relation. Indian Journal of Marine Sciences 9(3): 189-200.

20. Parulekar AH, Ansari ZA, Ingole BS (1986) Effect of mining activities on the clam fisheries and bottom fauna of Goa estuaries. Proceeding of Indian Academy Sciences. (Animal Sci) 95(3): 325-339.

21. Ansari ZA, Sivadas S, Ingole BS (2007) Benthic macrofauna. In: Shetey R, Dileep Kumar M, Shankar D (Eds.), The mandovi and Zuari estuaries. SSpecial publication of NIO pp. 91-98.

22. Verma KK, Cherian T (1975) Physical characteristics of Chapora estuary. Mahasagar-Bulletin of National Institute of Oceanography 8(3-4): 193-197.

23. Untawale AG, Dhargalkar VK (1986) Ecological studies of Ulva reticulata Forsskal in Chapora Bay (Goa). Mahasagar-Bulletin of National Institute of Oceanography 19: 175-184.

24. Snelgrove PVR, Butman CA (1994) Animal-sediment relationships revisited: cause versus effect. Oceanography Marine Biology an Annual Review 32: 111-177.

25. Sivadas S, Ingole B, Nanajkar M (2011) Temporal variability of macrofauna from a disturbed habitat in zuari estuary, west coast of India. Environmental Monitoring \& Assessment 173(1-4): 65-78.

26. Lancellotti DA, Stotz WB (2004) Effect of shoreline discharge of iron mine tailing on a marine soft bottom community in northern Chile. Marine Pollution Bulletin 48(3-4): 303-312.

27. Ansari ZA, Ingole BS, Furtado, Ramila (2002) Response of benthic fauna to different pollutants. Some case studies and relevance of benthos to environmental impact assessment. In: Hiremath G (Ed.), Recent Advances in Environmental Sciences. Discovery publishing house New Delhi, India, p. 422-428.

28. Modassir M (1994) Impact of current iron ore mining activities on the environment of Goa and proposed measures to minimize long term environmental damage. MBA Thesis submitted to University of Hull, UK.

29. Panchang R, Nigam R, Baig N, Nayak GN (2005) A foraminiferal testimony for the reduced adverse effect of mining in Zuari estuary, Goa. International journal of Environmental studies 62(5): 579-591. 
30. Anonymous, 1981. Eco-development plan for Goa (Report of Task Force on coastal area planning. p. 42.

31. Agadi VV, Bhosale NB, Untawale AG (1978) Metal concentration in some seaweeds of Goa. Botanica Marina 21(4): 247-250.

This work is licensed under Creative

Commons Attribution 4.0 Licens

OI: 10.19080/OFOAJ.2018.08.555737
32. Choudhuri SK (1994) Water pollution, environmental aspects of mining areas, Bulletin No. 27, Indian Bureau of Mines. pp. 37-40.

33. Mesquita A, Kaisary S (2007) Distribution of iron and manganese. In: Shetey SR, Dileep Kumar M, Shankar D (Eds.), The Mandovi and Zuari estuaries. Special publication of NIO pp. 99-104.

\section{Your next submission with Juniper Publishers will reach you the below assets}

- Quality Editorial service

- Swift Peer Review

- Reprints availability

- E-prints Service

- Manuscript Podcast for convenient understanding

- Global attainment for your research

- Manuscript accessibility in different formats

( Pdf, E-pub, Full Text, Audio)

- Unceasing customer service

Track the below URL for one-step submission

https://juniperpublishers.com/online-submission.php 